\title{
Scientific Study of Amish Tripathi's Novels
}

Sangeeta Tripathi

Research Scholar

Gurukul Kangri University

Haridwar, Uttrakhand, India

sangeeta23628@gmail.com

Dr. Mudita Agnihotri

Supervisor, English Professor

Kanya Gurukul Campus

Haridwar, Uttarakhand, India

Abstract

Amish Tripathi is a rising contempory writer. His passion towards Indian mythology inspired him to write about Hindu Mythology upon Hindu God and Goddesses. He is one of the best selling author in English literature, written about mythological stories. All the novels of Amish Tripathi are modernized in such a way that it can match with the interest of today's generation. His novels are about society, women, oppressed classed etc. Apart from these his novels are full in scientific techniques. There are so many scientific concepts in the novel 'Shiva Triology'. There are three parts in Shiva triology. The first part is the immortals of Melutra, the second part is the secret of the Nagas and the third part is the oath of vayuputras. The concept like Radiowaves, manufacture of somras, Divizian of cell etc. are scientifically explained in the novel Shiva triology.

Keywords - Mythololgy, Society, Scientific techniques, Radio waves, Division of cells etc. 
Mythological stories in Hindu culture have its unique place. Hindu mythological stories are famous in India even in all over the world. Amish Tripathi has taken mythological stories and modernized it in his novels. By reading his novel, one can understand that scientists and their experiments are not new, also but in history it was performed. In the novel Shiva triology there are various concepts like Radio waves, cell division and modern facilities are explained in scientific manner. The first and most important is 'Somras'. The somras is manufacture in meluha in large amount. The meluhan cheif scientists Brahaspti explained to Shiva:

"After a lot of research, Lord Brahma invented the Somras, which when consumed, reacts with the oxidants, absorbs them the then expels them from the baby as sweat or urine. Because of the somras, there are no oxidants left in the body."

(The immatals of Meluha, page 137)

The meluhans drink somras for long time youth, for immunity power. But, in reality they didn't know it side effects that how dangerous could be drinking it. They causes many disease like deformities in Nagas children, plague and the main is the manufacture of somras, the Sarswati River in extincting in the meluha. Manufacture also causes river pollution in Tsangpo river because after its manufacture there are several waste products remained that are thrown in the river. The river lost its purity. In this way, Amish Tripathi has raised serious matter of water pollution preventing in the country now a days. The river like Ganga and Yamuna are on the way to extinction.

In the novel Shiva triology Nagas children becomes deform after drinking water of polluted river. Deformities like extra hand, mishapen face which resembles like elephant. In the novel Kali and Ganesha represented as Nagas because Kali has two extra functioning hands and Ganesha face is like elephant. The main cause for the deformities of the nagas in division of cells after drinking the somras. This whale process is explained by the Brahaspati. 
"The cells keep dividing while remaining healthy. In most people, this continued division is regulated. But in a few, some cells lose control over their division process and keep growing at an exponential pace."

(The Oath of the Vayuputras P.No. 16)

In the novel it is scientifically explained that division of cells causes cancer. The faster division of cells continue to grow and appear as deformities. In our Hindu mythology, there is different story behind the long nose of Ganesha, but in Amish Tripathi's novel it is scientifically explained why his nose in long like an elephant. He was a Nagas child, due to his deformities he was denounced by king Daksha. Queen Kali was the leader of the Nagas.

In science we study about how food provides us energy. The food that we eat stores energy "we feel weak when we do not eat the food. We cannot get energy by eating only, something in the body draws energy from the food. The conversion of food into energy is performed by the air we breathe. The air contains various gases in it which helps in the process. One of these gases is called oxygen, which reacts with the food and releases energy. It we don't get oxygen, our body would be starved by energy and we would die. The scientific concept about the colours of leaf is being explained by the Pandit to Shiva. It is called 'theory of colours'. In the novel 'immortal of meluha process is explained.

"While Sunlight falls on the leaf the leaf's physical properties are such that it absorbs the colours voilet, indigo, blue, yellow, orange and red. It doesn't absorbs the colour green, while is the reflected back to eyes. Hence we see the leaf as green." (IM of Meluha, page 298)

As above mentioned there are so many scientific concepts being mentioned by Amish Tripathi. The process of making Somras is explained in such a way that scientists are really works in the Laboratory. The concept of Radio waves is beautifully presented by Amish Tripathi. The radio waves are used in communication, air-traffic control, cellular technology 
etc. In today's day to day life we are dependent on waves to hear. Sound waves travel much slower through the air and for much shorter distances. Radio waves travel for and fast, just like light. In the novel secret of Nagas Pandit explained to Shiva about the radio waves.

"This is not a theory. This certainly not a theory. This a fact. Just like light, which help you to see, there are radio waves to help you hear."

(The secret of the Nagas, page 104)

The whole concept have taken from our past. There are so many examples in the novel shows that history supports science. Besides this their many terms like bedsheets, Hygeine, shower etc. represents the modern term. When Shiva and his team reached to Meluha they got surprised to see the modern facilities of meluha. There are three-storyed buildings had comfortable and separate living quarters for each family. Each room had luxrious furniture including a highly polished copper plate on the wall in which one could see the reflection. The capital city of meluha was Devagini. The city was built on giant platforms, an effective protection against floods as well as from the enemies. All the platforms were connected to each other by all tall bridges made up of stones and baked brick. All these things made Shiva awestruck. These all equipments were scientifically made for the convenience of their people. In, the Hnidu mythology we all know that Shiva has drunk the poison so that his neck turned blue, but in the novel Shiva triology Amish Tripathi has explained it scientifically. These are some chemical reactions which Shiva necked book blue. In his childhood his uncle monoblue used to give him same medicine. After grownup when Shiva came to Meluha from Tibet he drink the Somras and chemical reaction occurred, Therefore his neck turned blue. The effect of the medicine remains darmant in the throat for years. Somras reacts with the traces of medicine already present in the man's throat to make his neck appear blue. 
Apart from these scientific techniques there are other examples of scientific techniques in the novels of Amish Tripathi. The weapons which are used in the novels are resembles like today's modern weapons like atomic bomb is likePashupatiastra and Deviastra is like nuclear bomb. The Pashupatiastra is a weapon designed by Lord Rudra. It has all the the qualities of atomic bomb. Amish Tripathi has re-interpreted the concept of atomic bomb thrown by the united states on Hiroshima and Nagasaki in 1945. The 'Chakravyuh' formation is also has been explained in the novels of Amish Tripathi. The charavyuh comprised calaumns of infantrymen in the tortoise position. The tortorise themselves were protected to rear by the river and the Sarswati fleet at anchar in the middle of the river chakravyuh would provide protection against the meluhan forces the might attack from the river end. Amish Tripathi has given his hundred percent of represent the society which is equivalent to modern Indian society. We can see the glimpse of modern facilities scientific techniques applied in modern was etc. A broad explanation of conversion of food into energy is being explained in the novel Shiva Triology. We can clearly understand the scientific explaination made in the novel-

"The food that we eat stores energy, which we can then expend. That's also why we feel weak when we don't eat." (IM page 136)

The writer has used both types of medicines in this novels i.e. Allopathy and Homeopathy. In the when Parvateshwar got injured, he was cured by both the means. There is a modern name mention by the writes in the novel 'internal hemorrhaging'. Ayurvati, the doctor of meluha said to Shiva about the condition of Shiva. The meluhans are very strict about their medical guidelines. The lady doctor Aryrvati is the first lady doctor of meluha. She is very strict about rules and regulation of Meluha. The person who comes outside from meluha put under seven days quartine. So that immigrants may not come in with new disease which can spread in Meluha. During these days doctors would observe them. Therefore, we 
have find that there are various terms and their explanation has been made by writer. For example it has explain scientifically the theory of colours, division of cells, Radio waves etc. Amish Tripathi has re-conceptualize the whole traditional story in very simple and interesting way, characters and incidents of history has been relate to present time. Amish Tripathi has achieved his goals for attracting the modern readers towards the mythology. He is truly the writes of present generation who understands our culture and tradition. 


\section{References}

Tripathi Amish, The Immortals of Meluha. New Delhi: Westland Ltd., 2010 Print. Tripathi Amish, The Secret of the Nagas. New Delhi: Westland Ltd. 2011 Print.

Tripathi Amish, The Oath of the Vayuputras. New Delhi: Westland Ltd. 2013.

Tripathi Amish, Scion of Ikshvaku. New Delhi: Westland. 2015.

Tripathi Amish, Sita : Warrior of Mithila. Westland Publication Ltd. 2017.

Tripathi Amish, Immortal India. Westland Publication. 2017. 